\title{
Seasonal assessment of drinking water sources in Rwanda using GIS, contamination degree (Cd), and metal index (MI)
}

\author{
Valentine Mukanyandwi $(D)$ Alishir Kurban • Egide Hakorimana • Lamek Nahayo • \\ Gabriel Habiyaremye • Aboubakar Gasirabo • Theoneste Sindikubwabo
}

Received: 22 January 2019/Accepted: 13 August 2019/Published online: 9 November 2019

(C) The Author(s) 2019

\begin{abstract}
The quality of drinking water source remains as a major concern in areas of developing and underdeveloped countries worldwide. The treatment and supply of drinking water in Rwanda are carried out by Water and Sanitation Corporation, a state-owned public company. However, it is not able to supply water to all households. Consequently, the non-serviced households depend on natural water sources, like springs, to meet their water requirements. Nevertheless, the water quality in these springs is scarcely known. Therefore, this study

\footnotetext{
V. Mukanyandwi · A. Kurban · E. Hakorimana ·

L. Nahayo · A. Gasirabo

Xinjiang Institute of Ecology and Geography, Chinese Academy of Sciences, 818 South Beijing Road, Urumqi 830011 Xinjiang, China

e-mail: valensmk@gmail.com
}

\author{
V. Mukanyandwi \\ V. Mukanyandwi \\ e-mail: valentinemuk@yahoo.fr \\ E. Hakorimana \\ e-mail: egideha@yahoo.fr \\ L. Nahayo \\ e-mail: lameknahayo@gmail.com
}

A. Gasirabo

e-mail: gasirab3@hotmail.com

V. Mukanyandwi · A. Kurban · E. Hakorimana •

L. Nahayo · A. Gasirabo

University of Chinese Academy of Sciences, Beijing 100049,

China assessed and compared metal elements in drinking water sources in the dry and rainy seasons in 2017 using the contamination degree, metal index, and geographic information systems to reveal the spatial distribution of water quality within the considered water sources of springs in Rwanda. The samples were collected monthly from nine water sources of springs and the measured elements are aluminium, calcium, copper, iron, manganese, and zinc. The metal index indicated that during the dry season and rainy season, the sites of Kibungo (1.10

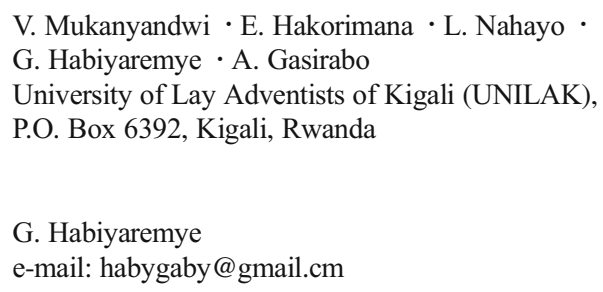

V. Mukanyandwi $\cdot$ A. Kurban $(\bowtie) \cdot$ E. Hakorimana $\cdot$

L. Nahayo · G. Habiyaremye · A. Gasirabo

Joint Research Center for Natural Resources and Environment in East Africa, P.O. Box 6392, Kigali, Rwanda

e-mail: alishir@ms.xjb.ac.cn

G. Habiyaremye

Lancaster Environment Centre, Faculty of Science and

Technology, Lancaster University, Lancashire LA1 4YQ, UK

T. Sindikubwabo

Water and Sanitation Corporation, Ltd., P. O. Box 2331, Kigali, Rwanda

e-mail: theonestesind7@yahoo.fr 
and 1.26) and Kinigi (1.01 and 1.54) have assessed a metal index which is higher than 1 . Thus, the water quality of those sites was getting the threshold of warning. The analysis indicated that pollutants are easily transported into water bodies during the rainy season in urban and rural areas to a greater extent than during the dry season .

Keywords Contamination degree $\cdot$ Metal index . Springs $\cdot$ Water quality $\cdot$ Rwanda

\section{Introduction}

Safe and affordable water is essential for public health. It is used for drinking, food production, domestic use, and recreational purposes. Access to improved water supplies and sanitation, along with better management of water resources, plays a crucial role in developing countries by impacting on communities' well-being and on national development plans (Onda et al. 2012; Wedgworth and Brown 2013; Nagar et al. 2015). However, access to safe drinking water is limited by global warming, rapid human population growth, inappropriate waste and wastewater management, housing styles, and geographical location. Rural dwellers have much more severe difficulties accessing clean water compared with urban residents (Tiwari et al. 2015; Wedgworth and Brown 2013; Hosseinifard and Aminiyan 2015). The pollution of drinking water sources is gradually increasing, due to limited financial capabilities and poor infrastructure, which force communities to directly consume water from farm wells, springs, and rainwater stores without prior treatment (Bempah and Ewusi 2016; Scott et al. 2017; Sahoo and Patra 2018).

The water quality is compromised by contaminants from anthropogenic sources, including industrial activities and agriculture, and the changing climate creates heavy storms and alters rainfall patterns, which affect the elements found in runoff (Elrashidi et al. 2015; Byer et al. 2011; Neogi et al. 2018). With the growing water demand, efforts have been consolidated to ensure access to safe water, such as creating buffer zone policies controlling the distance for various land uses from water bodies, pollutant reduction, highlighting the role of different stakeholders in water management, water purification, and waste and wastewater treatment (Khan et al. 2015; Juahir et al. 2011).
There has been much attention from local governments, governmental organizations, and NGOs but the burden is still primarily in developing countries (Mdegela et al. 2009). For example, since 1900, 2.6 billion people have gained access to safe water, but inequality still exists. In 2015, 663 million people, representing about 1 in 10 of the world's population, were drinking unsafe water, and the most affected areas are countries in sub-Saharan Africa (Aboniyo et al. 2017; Allen et al. 2013; Goher et al. 2014; Bidkhori et al. 2018).

In Rwanda, the high population density, expanding industrialization and urbanization, inappropriate waste and wastewater management, high rainfall intensity, and the country's high elevation are among the key sources of water pollution (Kirby et al. 2016; Nahayo et al. 2016). This pollution is associated with the cost of traveling to and the location of piped water in rural areas, which encourages the residents to use unsafe water. There are also poor sewage systems and common use of public latrines and septic tanks in both rural and urban areas (Aboniyo et al. 2017). Although several scholars (Doyle and Shanahan 2010; Karamage et al. 2016; Nsengimana et al. 2012; Nhapi et al. 2011) have conducted water quality assessments, they lacked the seasonal measurements necessary for understanding temporal changes in water quality, so that appropriate seasonal drinking water source management mechanisms can be applied. Regular water quality assessment would help water resource managers, environmental health officers, and the whole community to better understand and correlate seasonal variability and drinking water quality. Therefore, this study aimed to assess and spatially distribute the concentration of metal elements in drinking water sources between the dry and rainy seasons to determine in which period the pollution of drinking water sources is highest, and suggest appropriate drinking water quality management measures for Rwanda.

\section{Materials and methods}

\section{Study area}

Rwanda is a landlocked country located in Central-East Africa, bordered by Uganda to the north, Burundi to the south, Democratic Republic of Congo to the west and Tanzania to the east (Mukanyandwi et al. 2018). Rwanda has two rainy and two dry seasons, referred to as long and short. The first rainy season runs from March to 


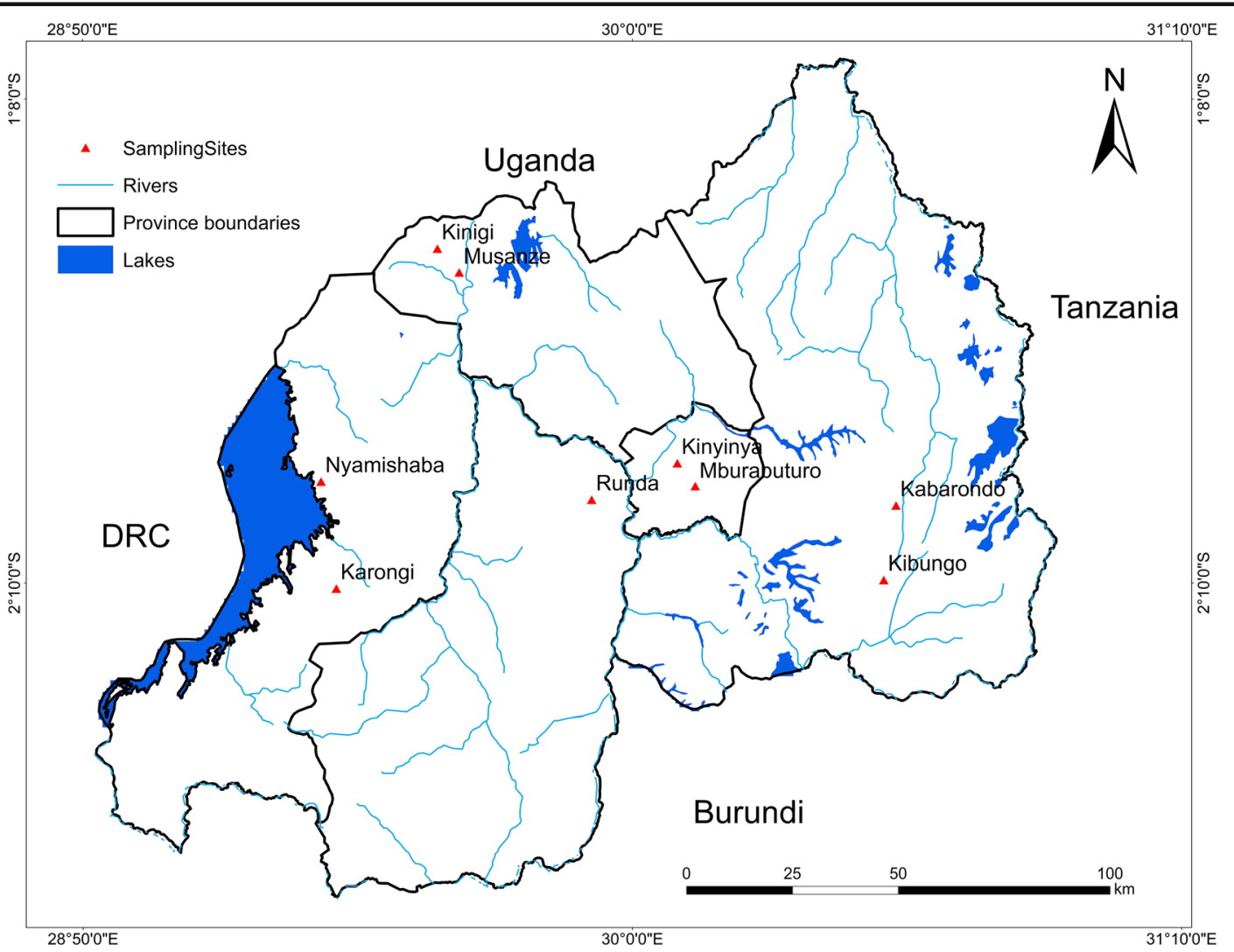

Fig. 1 Water sampling locations and the water network in Rwanda

May and the second spans late September to November, with an average rainfall of 110-200 mm per month. Rwanda also has two dry seasons; the first (short) dry season lasts from December to the end of February, while the longer one begins in June and runs to early September. The average temperature ranges between 19 and $27^{\circ} \mathrm{C}$ (Nahayo et al. 2018).

In Rwanda, there are abundant water resources (Fig. $1)$. The total area of Rwanda is 26,338 square kirometers, including about 128,190 ha of lakes, 7260 ha of rivers, and 77,000 ha are occupied by marshlands. In addition, there are about 22,300 springs (Ali et al. 2014; Nsengimana et al. 2012). To ensure that water undergoes prior treatment and to increase access to safe drinking water, about sixteen water treatment plants are operating countrywide. These initiatives have increased the percentage of people accessing safe drinking water from $23 \%$ in 1990 to $82 \%$ in 2016 (Rutanga and Niyigena 2016; Karamage et al. 2016) . Therefore, The water samples were collected from springs in different areas in country to ensure that the water quality of selected springs is healthy according to the World Health Organization for metals in water(Table 1).
Field sample collection and experimental approaches

The water samples were collected from nine drinking water sources located in urban, semi-urban, and rural areas of Rwanda, during the dry season (July-September) and rainy season (October-December), respectively.

The authors collected three water samples monthly from each sampling site from a foot be-

Table 1 Names and location of the sampling sites

\begin{tabular}{lll}
\hline No & Sampling sites & Location (province) \\
\hline 1 & Kinyinya & Urban, Kigali city \\
2 & Mburabuturo & Urban, Kigali city \\
3 & Runda & Semi-Urban, Southern Province \\
4 & Kabarondo & Semi-Urban, Eastern Province \\
5 & Kibungo & Rural Eastern Province \\
6 & Musanze & Semi-urban, Northern Province \\
7 & Kinigi & Rural, Northern Province \\
8 & Karongi & Semi-urban, Western Province \\
9 & Nyamishaba & Rural Western Province \\
\hline
\end{tabular}


Fig. 2 Average monthly rainfall recorded at meteorological stations neighboring the water sampling sites

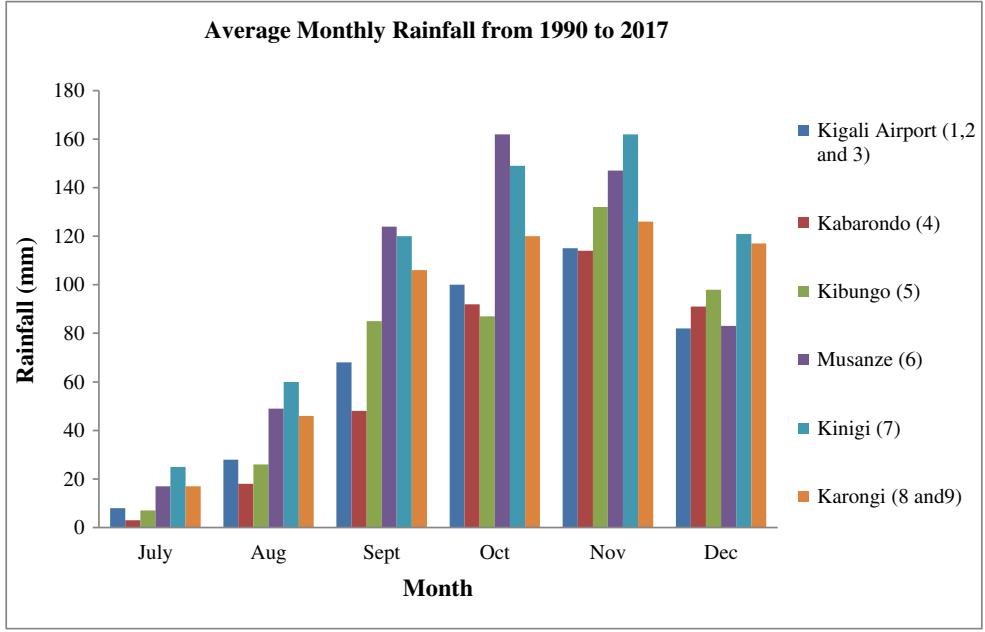

low the water surface. The samples were preserved in acid-washed $100-\mathrm{mL}$ polypropylene bottles to avoid changes in characteristics, and were digested, concentrated, and prepared for analysis by atomic absorption spectrophotometry (AAS) using an AA Spectrometer M Series.

We conducted extensive monthly water quality monitoring and the measured elements were calcium $(\mathrm{Ca})$, iron $(\mathrm{Fe})$, manganese $(\mathrm{Mn})$, copper $(\mathrm{Cu})$, aluminium $(\mathrm{Al})$, and zinc $(\mathrm{Zn})$. The drinking water samples of dry and rainy seasons were compared, the monthly maximum rainfall $(\mathrm{mm})$ records at each meteorological station neighboring the water sampling site were obtained (Fig. 2) for July, August, and September for the dry season, and October, November, and December for the rainy season of 2017. During the analysis, the rainfall variability was referred to in order to better understand how changes in rainfall might influence the drinking water quality.
Indexing approach

\section{Metal index}

This study used the metal index (MI); it is generally used for metals in drinking water quality (Goher et al. 2014). The metal index takes into account possible additive effect of metal elements on the human health that help to quickly evaluate the overall quality of drinking waters. Metal index is given by the expression proposed by Caeiro et al. (2005) and is calculated as indicated below:

$M I=\sum_{i=1}^{n} \frac{C I}{(\mathrm{MAC}) i}$

where MAC is the maximum allowable concentration and $\mathrm{Ci}$ is the mean concentration of each element. The higher concentration of metal was compared with its respective MAC value that

Table 2 Concentration and mean value of metal elements during the dry season

\begin{tabular}{lllllllllll}
\hline Sites & 1 & 2 & 3 & 4 & 5 & 6 & 7 & 8 & 9 & Mean/element \\
\hline $\mathrm{Ca}$ & 43.6 & 54 & 61.4 & 31 & 91.8 & 63.2 & 84 & 21 & 26 & 52.88 \\
$\mathrm{Fe}$ & 0.38 & 1.14 & 0.2 & 0.39 & 0.33 & 0.09 & 0.2 & 0.2 & 0.09 & 0.33 \\
$\mathrm{Mn}$ & 0.4 & 0.21 & 0.02 & 0.17 & 0.32 & 0.01 & 0.4 & 0.003 & 0.11 & 0.18 \\
$\mathrm{Cu}$ & 0.51 & 0.28 & 0.13 & 1.31 & 1.1 & 0.18 & 0.03 & 0.41 & 0.12 & 0.45 \\
$\mathrm{Al}$ & 0.03 & 0.11 & 0.03 & 0.16 & 0.03 & 0.12 & 0.11 & 0.08 & 0.09 & 0.08 \\
$\mathrm{Zn}$ & 0.38 & 0.38 & 0.4 & 0.54 & 0.37 & 0.10 & 1.01 & 0.11 & 1 & 0.47 \\
Mean/site & 7.55 & 9.35 & 10.36 & 5.59 & 15.65 & 10.61 & 14.29 & 3.63 & 4.56 & \\
\hline
\end{tabular}


Table 3 Concentration and mean value of metal elements during rainy season

\begin{tabular}{lllllllllll}
\hline Sites & 1 & 2 & 3 & 4 & 5 & 6 & 7 & 8 & 9 & Mean/element \\
\hline $\mathrm{Ca}$ & 75.2 & 92 & 82 & 72.8 & 102.7 & 77.1 & 127.1 & 37.8 & 32.1 & 77.46 \\
$\mathrm{Fe}$ & 0.71 & 1.24 & 0.61 & 0.43 & 0.65 & 0.07 & 0.08 & 0.18 & 0.13 & 0.45 \\
$\mathrm{Mn}$ & 0.16 & 0.26 & 0.14 & 0.32 & 0.44 & 0.2 & 0.15 & 0.04 & 0.14 & 0.2 \\
$\mathrm{Cu}$ & 0.65 & 1.46 & 0.8 & 1.78 & 1.9 & 0.2 & 1.06 & 0.84 & 1.17 & 1.09 \\
$\mathrm{Al}$ & 0.09 & 0.32 & 0.06 & 0.28 & 1.01 & 0.15 & 0.86 & 0.14 & 0.19 & 0.34 \\
$\mathrm{Zn}$ & 0.8 & 0.83 & 0.9 & 0.76 & 0.58 & 1.13 & 1.08 & 0.14 & 1.04 & 0.79 \\
Mean/site & 12.93 & 16.01 & 14.08 & 12.72 & 17.88 & 13.14 & 21.72 & 6.52 & 5.79 & \\
\hline
\end{tabular}

shows the worse quality of water. MI value $>1$ is a threshold of warning (Bakan et al. 2010). Water quality and its suitability for drinking purpose can be examined by determining its metal pollution index (Mohan et al. 1996; Reza and Singh 2010). This study applied the above metal index for the estimate value of six metal elements, namely, aluminium, calcium, manganese, copper, iron, and zinc.

\section{Contamination degree $(C d)$}

The contamination degree is defined as the sum of all concentration factors (Rahman et al. 2014). The water samples are classified by calculating the degree of contamination in water samples. Contamination degree, by added various parameters assuming water quality, investigates the convenience of drinking water samples for municipal consuming (Backman et al. 1998). The contamination degree has to be calculated split up for all samples, based on the surpassed parameters from standard values.

This index is calculated as follows:
$\mathrm{Cd}=\sum_{i=1}^{n} \mathrm{Cf}_{\mathrm{i}}$

$\mathrm{Cf}_{\mathrm{i}}$ can be obtained from Eq. (3)

$\mathrm{Cf}_{\mathrm{i}}=\frac{\mathrm{CA}_{\mathrm{i}}}{\mathrm{CN}_{\mathrm{i}}}-1$

Where:

$\mathrm{Cf}_{\mathrm{i}} \quad$ is the contamination factor for the $i$ th parameter

$\mathrm{CA}_{\mathrm{i}}$ is the measured value for the $i$ th parameter

$\mathrm{CN}_{\mathrm{i}}$ is the standard allowed value for the $i$ th parameter

\section{Result}

The results illustrated in Tables 2 and 3 indicated gradual increase of the values of metal elements, particularly during the dry season (July-September 2017) compared with the values noted during the rainy season (OctoberDecember 2017). The mean concentrations of the analyzed metals were used to calculate the metal index (MI) and contamination degree $(\mathrm{Cd})$ during both seasons and

Table 4 The metal index and contamination degree of measured elements during the dry season (ds) and rainy season (rs)

\begin{tabular}{|c|c|c|c|c|c|c|c|}
\hline $\begin{array}{l}\text { Metal } \\
\text { elements }\end{array}$ & $\begin{array}{l}\mathrm{Ci} \text { or } \mathrm{CAi} \text { in ds } \\
(\mathrm{mg} / \mathrm{L})\end{array}$ & $\begin{array}{l}\text { (MAC)i or } \\
(\mathrm{CNi}) / \mathrm{mg} / \mathrm{L}\end{array}$ & $\begin{array}{l}\mathrm{Ci} \text { or } \mathrm{CAi} \text { in } \\
\mathrm{rs}\end{array}$ & MI (ds) & MI (rs) & $\begin{array}{l}\mathrm{Cd} \\
(\mathrm{ds})\end{array}$ & $\begin{array}{l}\mathrm{Cd} \\
(\mathrm{rs})\end{array}$ \\
\hline $\mathrm{Ca}$ & 52.88 & 80.0 & 77.46 & 0.66 & 0.92 & -0.34 & -0.08 \\
\hline $\mathrm{Fe}$ & 0.33 & 0.3 & 0.45 & $\begin{array}{l}1.1 \text { (threshold of } \\
\text { warning) }\end{array}$ & $\begin{array}{l}1.49 \text { (threshold of } \\
\text { warning) }\end{array}$ & 0.1 & 0.49 \\
\hline $\mathrm{Mn}$ & 0.18 & 0.1 & 0.2 & $\begin{array}{l}1.8 \text { (threshold of } \\
\text { warning) }\end{array}$ & $\begin{array}{l}2.00 \text { (threshold of } \\
\text { warning) }\end{array}$ & 0.8 & 1.00 \\
\hline $\mathrm{Cu}$ & 0.45 & 1.0 & 1.09 & 0.45 & $\begin{array}{l}1.09 \text { (threshold of } \\
\text { warning) }\end{array}$ & -0.55 & 0.09 \\
\hline $\mathrm{Al}$ & 0.08 & 0.2 & 0.34 & 0.40 & $\begin{array}{l}1.70 \text { (threshold of } \\
\text { warning) }\end{array}$ & -0.60 & 0.70 \\
\hline $\mathrm{Zn}$ & 0.47 & 3.0 & 0.79 & 0.15 & 0.26 & -0.85 & -0.74 \\
\hline
\end{tabular}


Table 5 Metal index and contamination degree of each sampling site

\begin{tabular}{lllll}
\hline Sampling sites & $\begin{array}{l}\mathrm{Cd} \\
\text { Dry season }\end{array}$ & $\begin{array}{l}\mathrm{Cd} \\
\text { Rainy season }\end{array}$ & $\begin{array}{l}\text { MI } \\
\text { Dry season }\end{array}$ & $\begin{array}{l}\text { MI } \\
\text { Rainy season }\end{array}$ \\
\hline 1 & -0.46 & -0.08 & 0.53 & 0.91 \\
2 & -0.33 & 0.13 & 0.66 & 1.13 (threshold of warning) \\
3 & -0.26 & 0.001 & 0.73 & 0.99 \\
4 & -0.6 & -0.09 & 0.39 & 0.90 \\
5 & 0.1 & 0.27 & 1.10 (threshold of warning) & 1.26 (threshold of warning) \\
6 & -0.24 & -0.06 & 0.75 & 0.93 \\
7 & 0.01 & 0.54 & 1.01 (threshold of warning) & 1.54 (threshold of warning) \\
8 & -0.74 & -0.53 & 0.25 & 0.46 \\
9 & -0.67 & -0.58 & 0.32 & 0.41 \\
\hline
\end{tabular}

the mean concentration of elements on sites were used to calculate the metal index and contamination degree of each sampling site.

Table 4 illustrates the metal index and the contamination degree of measured metal elements in drinking water sources.

The table below represents the metal index for each drinking water sampled during both seasons and it also indicates the sites which are on a threshold level of warning according to their recorded metal index value (Table 5).

According to Caeiro et al. (2005) and Lyulko et al. (2001), the classification of metal index to the drinking water quality classifies into six different classes and their characteristics as illustrated in Tables 6 and 7.

The contamination degree classifies drinking water quality into three different classes as illustrated in the Table 7; it revealed that all sampled sites were classified in class 1 which is characterized by low contamination where the $\mathrm{Cd}<1$ (Table 6).

Figures $3,4,5,6,7,8,9$, and 10 represent the spatial distribution of each metal element during the dry and rainy seasons.

Table 6 Classification of metal index

\begin{tabular}{|c|c|c|c|c|}
\hline MI & Characteristics & Class & $\begin{array}{l}\text { Site no. in } \\
\text { dry season }\end{array}$ & $\begin{array}{l}\text { Site no. in } \\
\text { rainy season }\end{array}$ \\
\hline$<0.3$ & Very pure & 1 & 8 & - \\
\hline $0.3-1.0$ & Pure & 2 & $\begin{array}{l}1,2,3,4 \\
6,7, \text { and } 9\end{array}$ & $\begin{array}{l}1,3,4,6 \\
8, \text { and } 9\end{array}$ \\
\hline $1.0-2.0$ & Slightly affected & 3 & 5 & 2,5 , and 7 \\
\hline $2.0-4.0$ & Moderately affected & 4 & - & - \\
\hline $4.0-6.0$ & Strongly affected & 5 & - & - \\
\hline$>6.0$ & Seriously affected & 6 & - & - \\
\hline
\end{tabular}

\section{Discussions}

As shown in Table 5 and Fig. 2, the sampling sites located in areas with high rainfall similarly recorded higher metal pollution index and higher contamination degree. This impact of rainfall patterns on water quality is marked by the results of this study; the rainfall acted effortlessly as a driver to water pollution, where high MI was recorded during the rainy season than MI during the dry season. The metal index and contamination degree per each sampling site indicated the high value of index during the rainy season at the sampling sites of Mburabuturo, Kibungo, and Kinigi compared with the metal index and contamination degree during the dry season, but also higher at the sampling site of Kibungo and Kinigi at large extent than other sampling sites. The maximum metal index was assessed at Kinigi site (1.34) during the rainy season and at Kibungo site (1.1) during the dry season (Table 5). Contingent on classification of metal index for drinking water quality, the average index for samples of dry and rainy seasons was 0.63 and 0.94 .

According to metal index's classification on water quality, during the dry season, most of the sites are classified in class 2 which is characterized as pure, while site 8 is classified in class 1 (very pure). Besides, site 5 is classified as slightly affected (class 3 ). The sites of 1, 3,

Table 7 Water quality classification using contamination degree (Cd)

\begin{tabular}{llll}
\hline $\mathrm{Cd}$ & Characteristics & Class & Sampling site \\
\hline $\mathrm{Cd}<1$ & Low contamination & 1 & All sampling site \\
$1<\mathrm{Cd}$ & Moderate contamination & 2 & \\
$\mathrm{Cd}>3$ & High contamination & 3 & \\
\hline
\end{tabular}



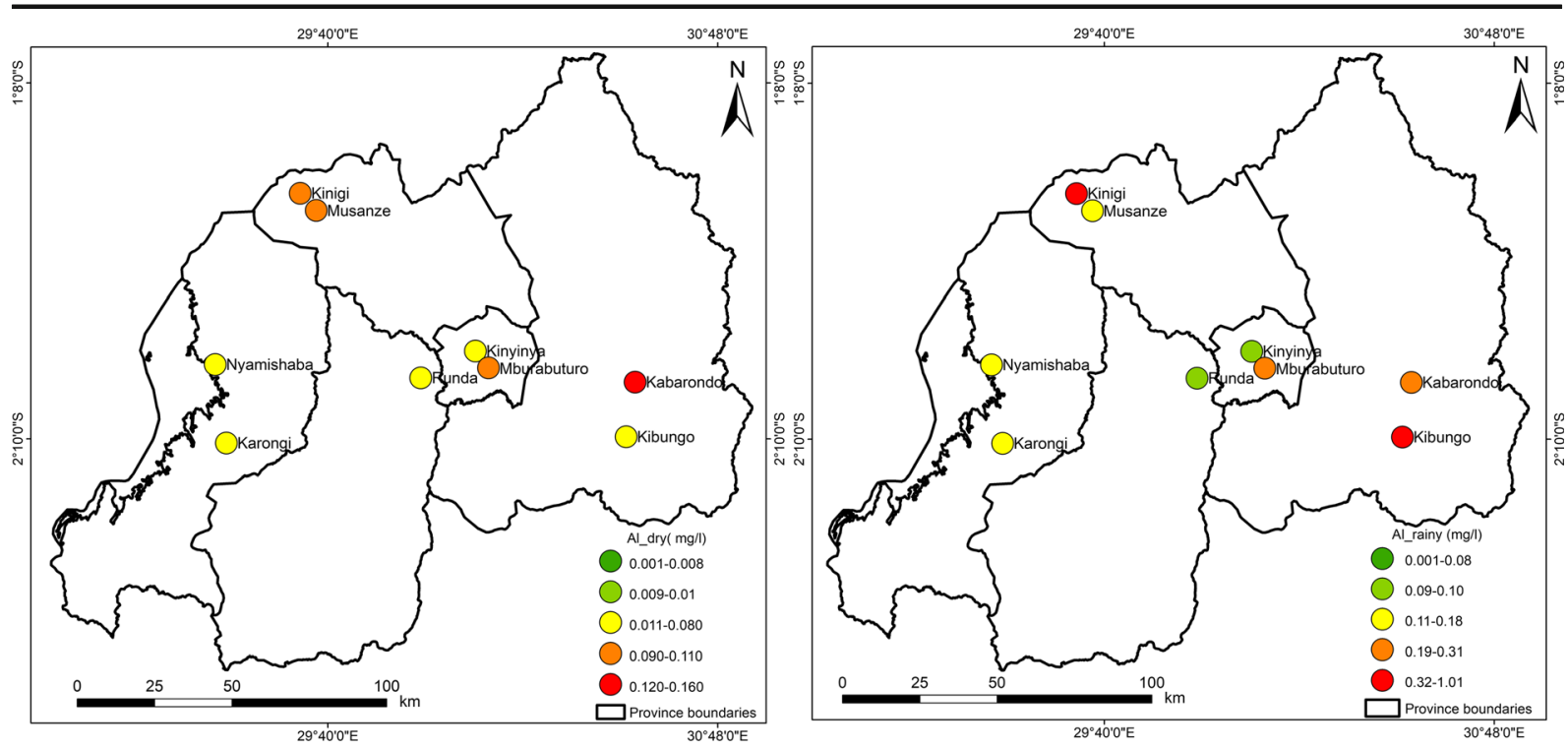

Fig. 3 Spatial distribution of aluminium during the dry and rainy seasons

$4,6,8$, and 9 are classified in class 2 (pure), whereas the sites 2,5 , and 7 are classified as slightly affected in class 3 (Table 6).

The maximum degree of contamination was recorded for the site of Kinigi (0.54) during the rainy season, while during the dry season, the maximum contamination degree was 0.1 for Musanze site; the minimum degree of contamination has been fixed for the Karongi site $(-0.74)$ in the dry season and $(-0.58)$ in the rainy season at Nyamishaba site (see Table 5). The contamination degree average for all the sites during the dry and rainy seasons is -0.35 and -0.04 , which are classified in class 1 as low degree of contamination.

In this study, drinking water sources located in urban areas, such as site of Kinyinya and Mburabuturo are polluted compare with the sampling sites located in rural areas. This agrees with previous reports (Srivastava et al. 2011; Lumb et al. 2011; Nyangababo et al. 2005) on water quality monitoring, which highlighted how urban waters are predominantly becoming polluted at high extent compared with that located in rural areas due to wastes generated by households, industries,
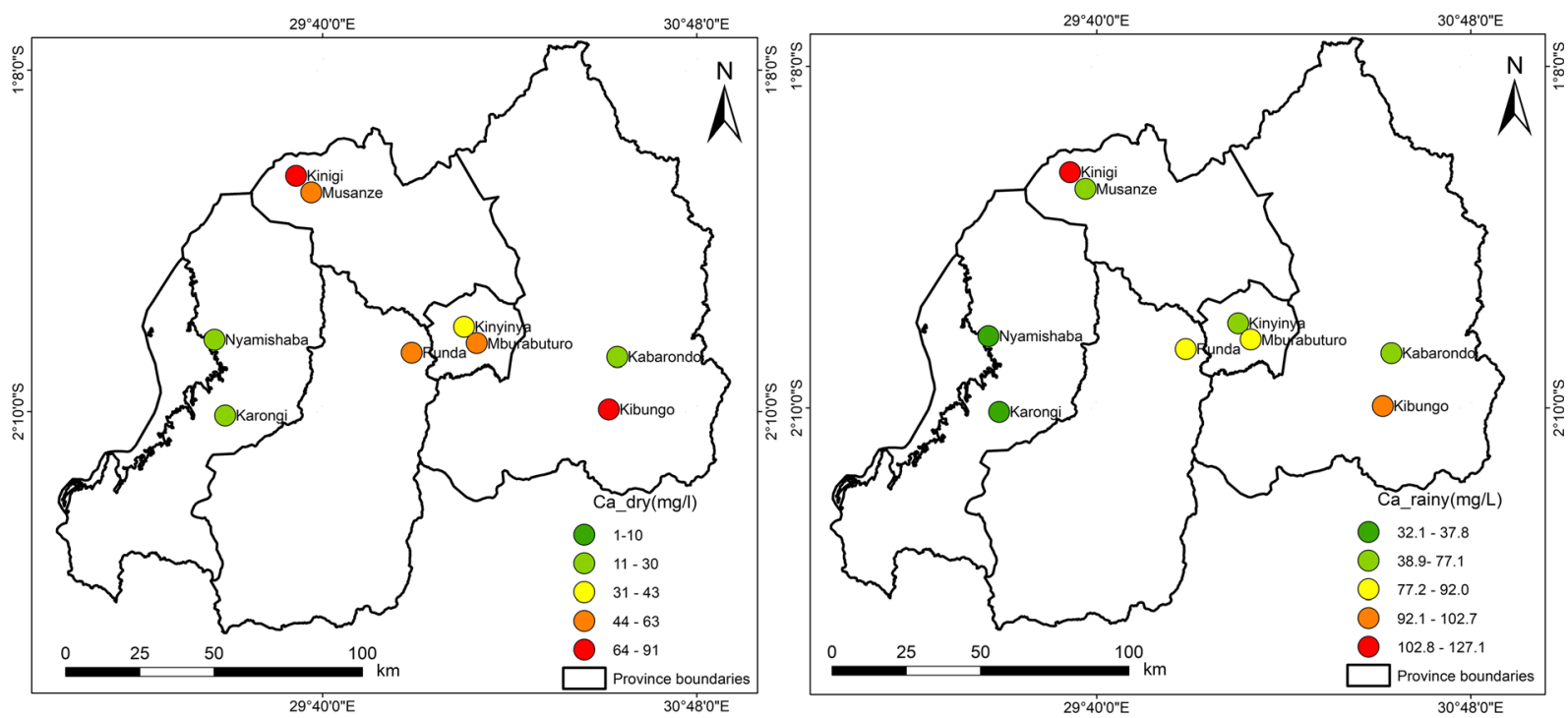

Fig. 4 Spatial distribution of calcium during the dry and rainy seasons 

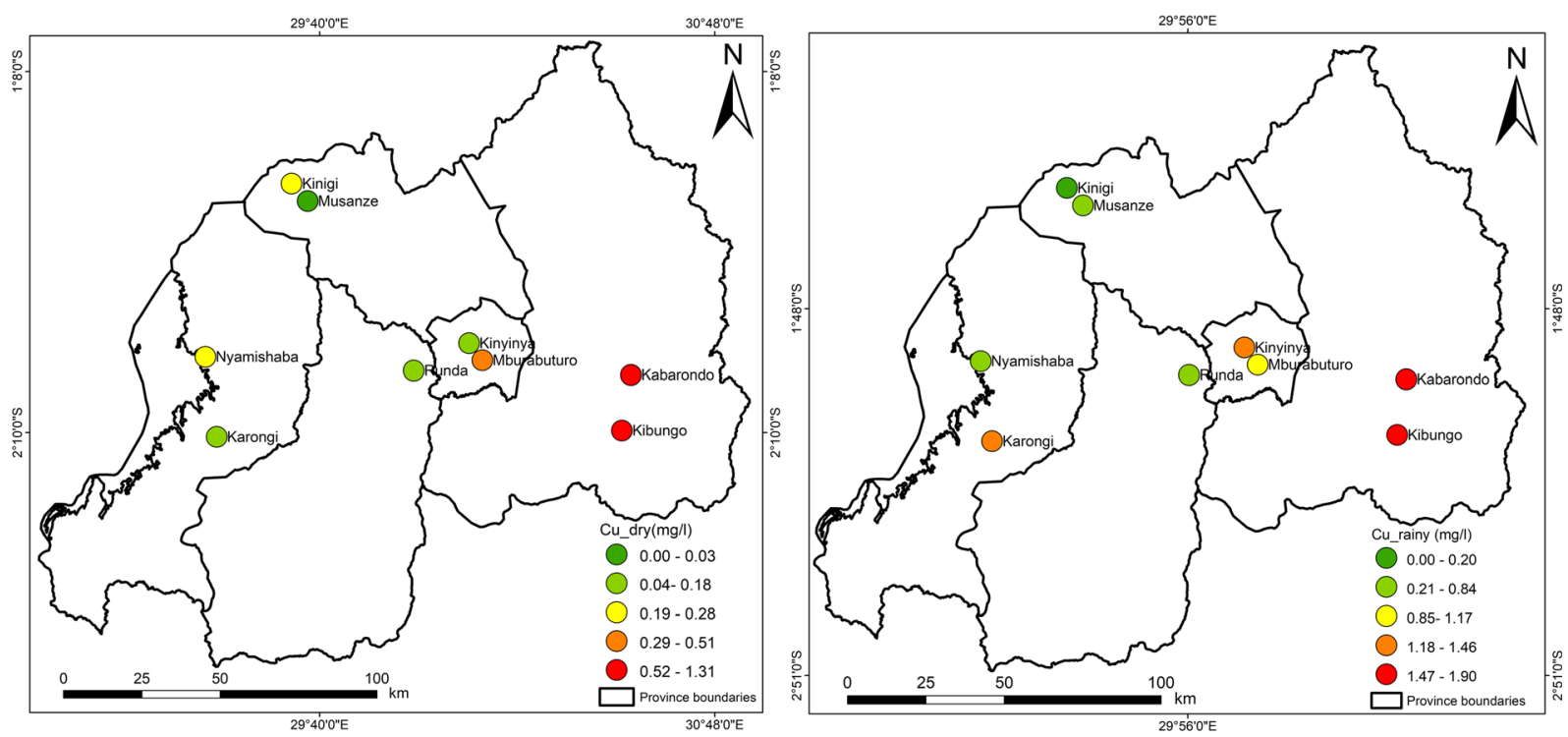

Fig. 5 Spatial distribution of copper during the dry and rainy seasons

slaughtering houses, directly thrown into waters, and other urban activities located nearby water bodies. Although the proportion of people accessing on safe drinking water increased in the last years in Rwanda, the results of this study (Fig. 8) showed that some people still consume polluted water, mostly during the rainy season than in the dry season. The iron and manganese are the key pollutants in the drinking water sources considered in this study (Table 5). Accordingly, it was observed that the consumers of polluted water sources might be subject to toxicity of the nervous system and cancer, liver, heart, and pancreatic damage as a result of excess manganese and iron, the highly noticed pollutants among other measured elements. Therefore, this expresses how rainfall undermines water quality as it facilitates easy pollutants runoff downwards water bodies. But also, on the other side, it calls for urgent rainfall management, such as rainfall harvest and/or use of bench terraces and agroforestry on hills surrounding the water bodies to minimize the runoff. This to be
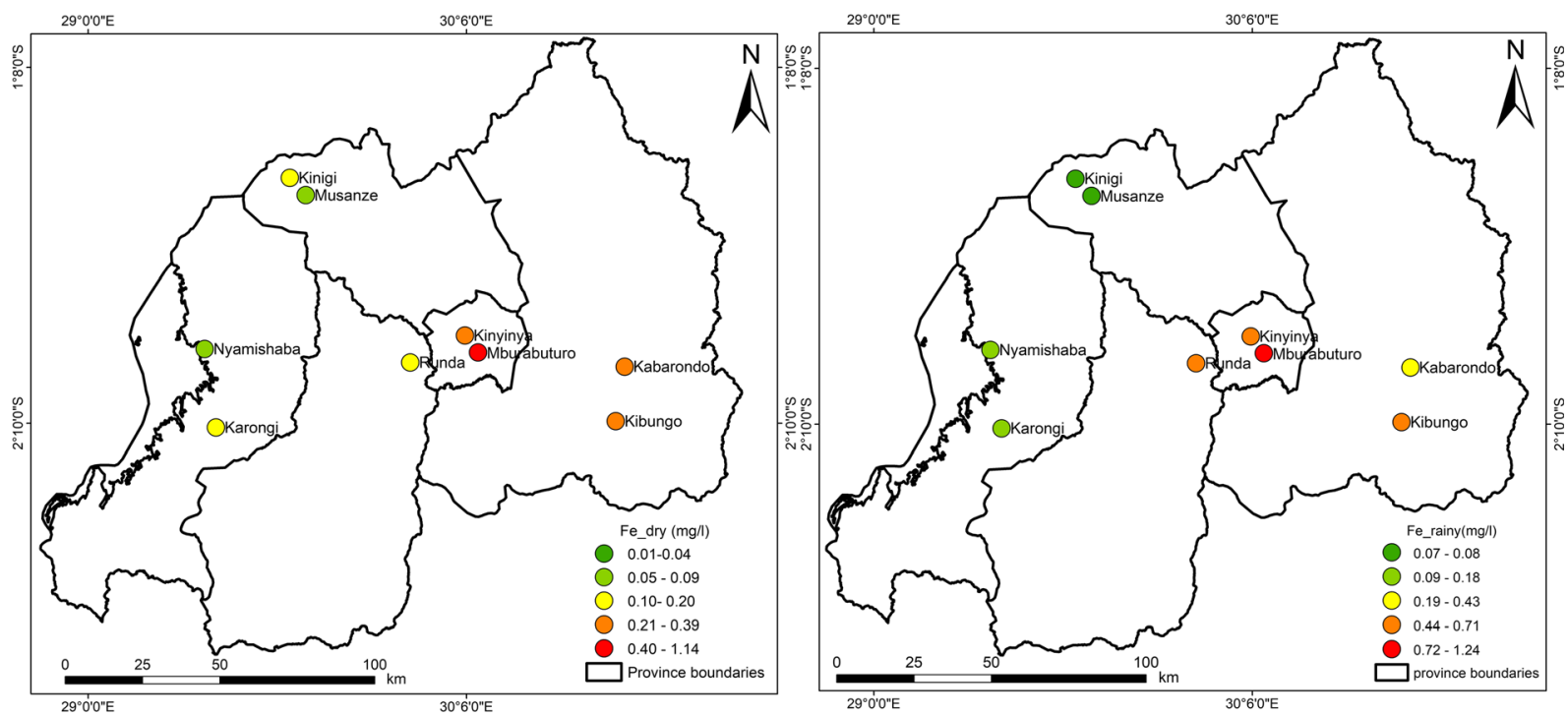

Fig. 6 Spatial distribution of iron in the dry and rainy seasons 

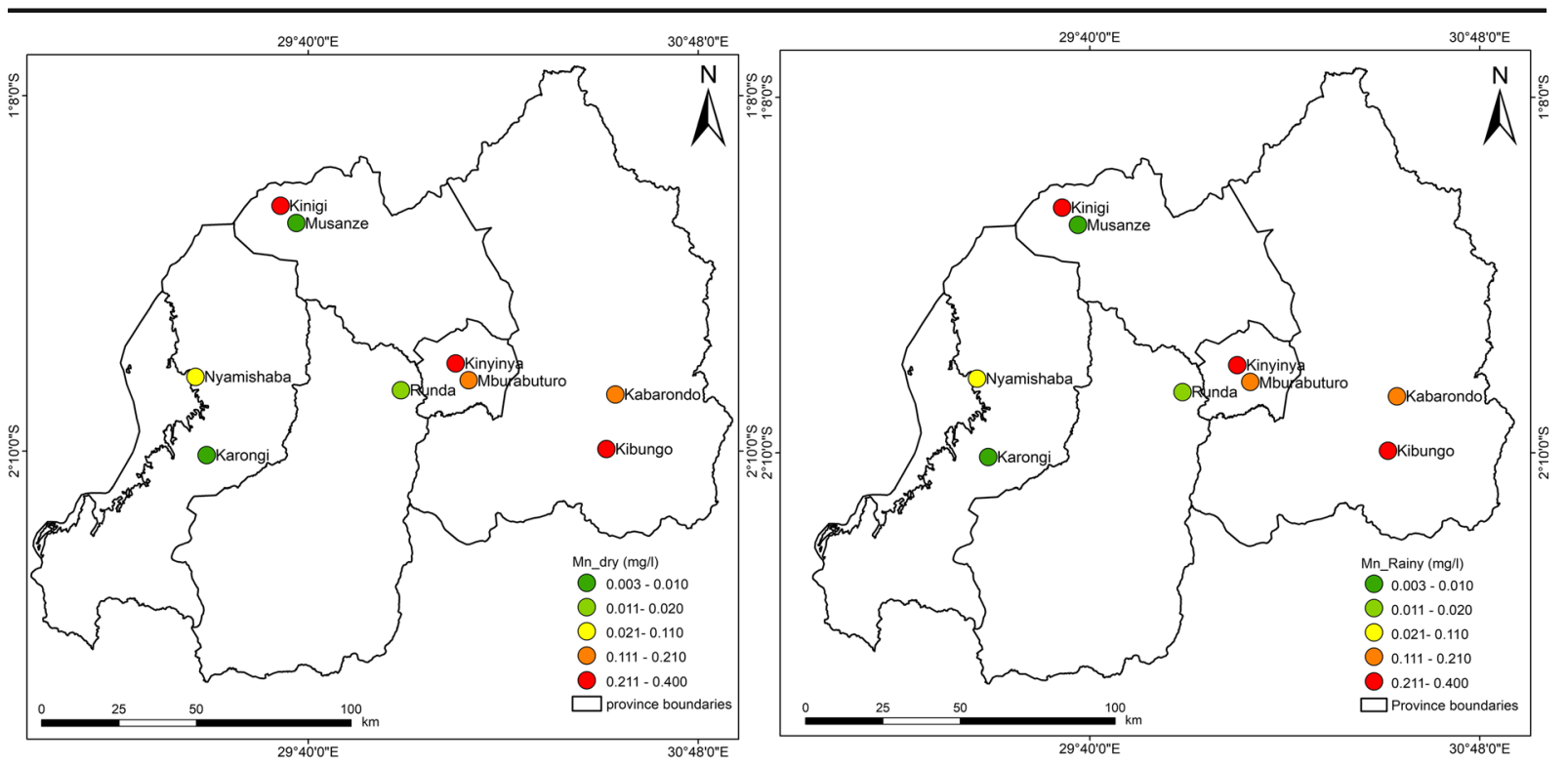

Fig. 7 Spatial distribution of manganese during the dry and rainy seasons

successful, it requires appropriate seasonal water quality management measures, specifically during the rainy season in urban areas than in rural areas to minimize the pollution likelihood of the available water sources (Fig. 1), which, in turn, affects water consumers' health. Furthermore, this will reduce the cost of water treatment and enhance community's wellness and natural resources management as well. Many researchers focused on seasonal evaluation of the assessment of metals in lakes and rivers (Low et al. 2016; Mukanyandwi et al. 2018; Rajeshkumar et al. 2018) but they did not work on the springs which are used with numerous people especially in developing countries. The accessibility of water supply is still inadequate in Rwanda; more than $38 \%$ of Rwandan people use natural sources including springs and the information about water quality of those springs was unknown. However, this study was contributed to assess and spatially distribute the metal concentration in drinking water by measuring in which season the drinking water is more polluted and to which extent the drinking water sources are polluted based on indices according to the drinking water quality standard.
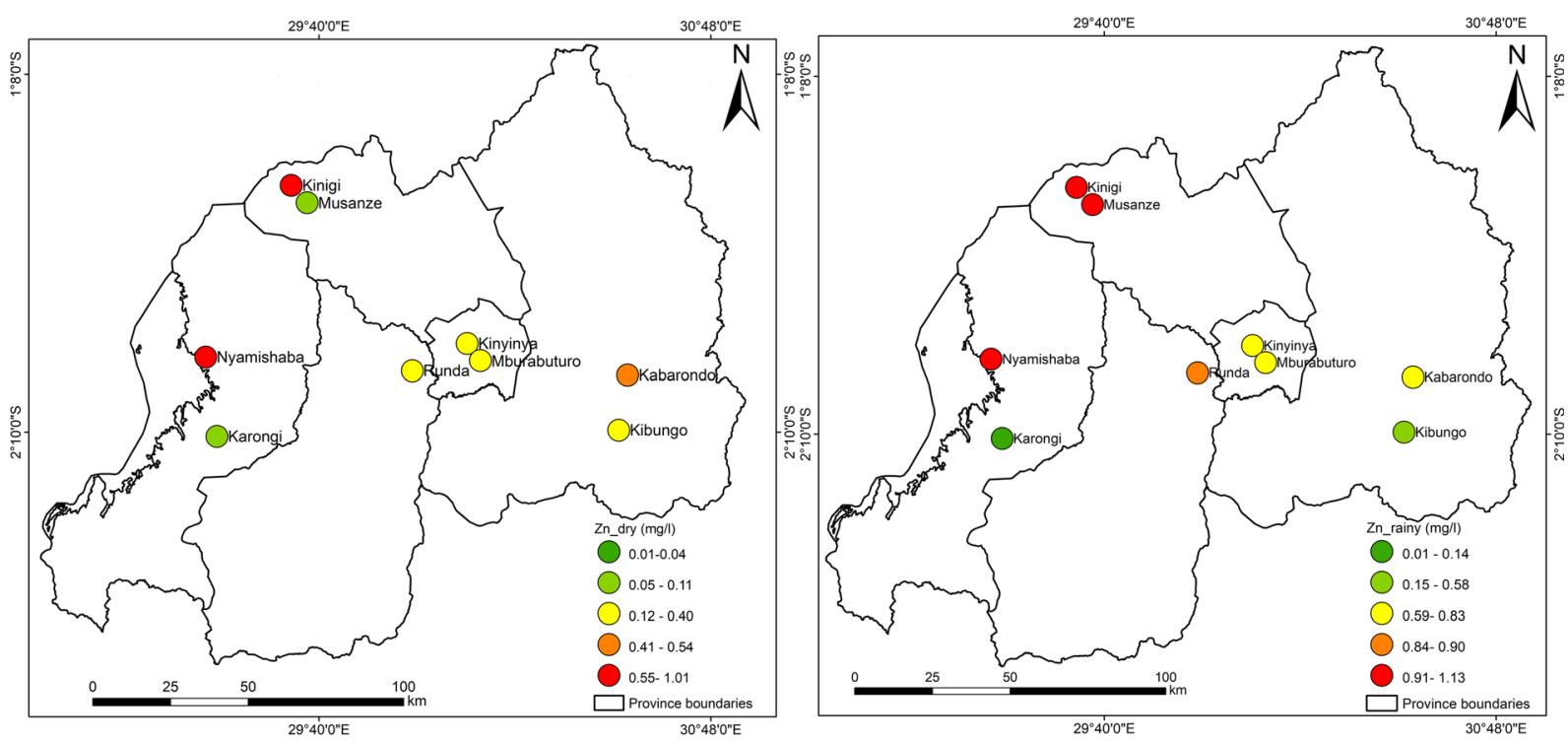

Fig. 8 Spatial distribution of zinc in the dry and rainy seasons 

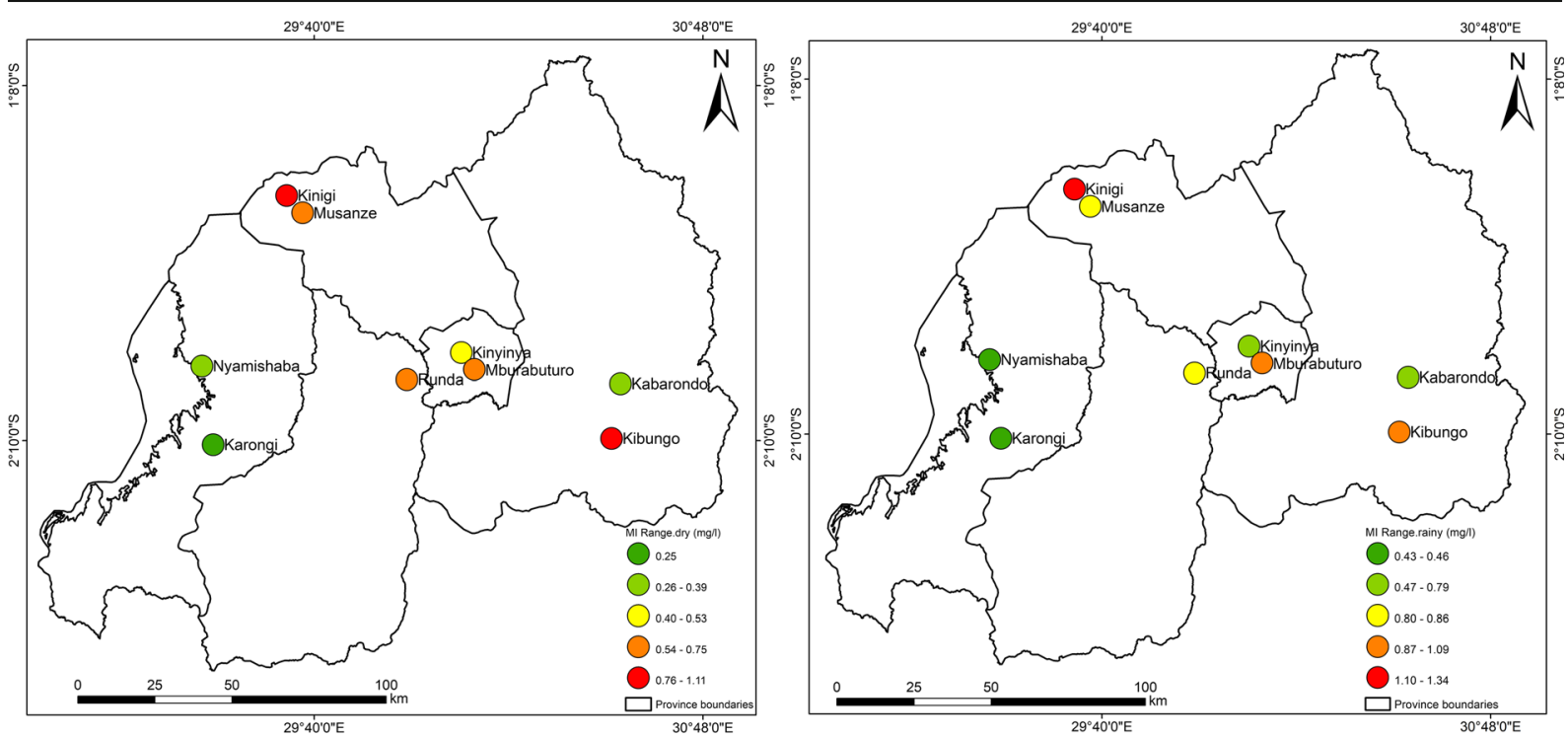

Fig. 9 Spatial distribution range of metal index (MI) for each sampling site

\section{Conclusion}

Water quality and scarcity are widespread problems and its sustainable management is becoming a quite challenge. Even though a range of resolving suggestions have

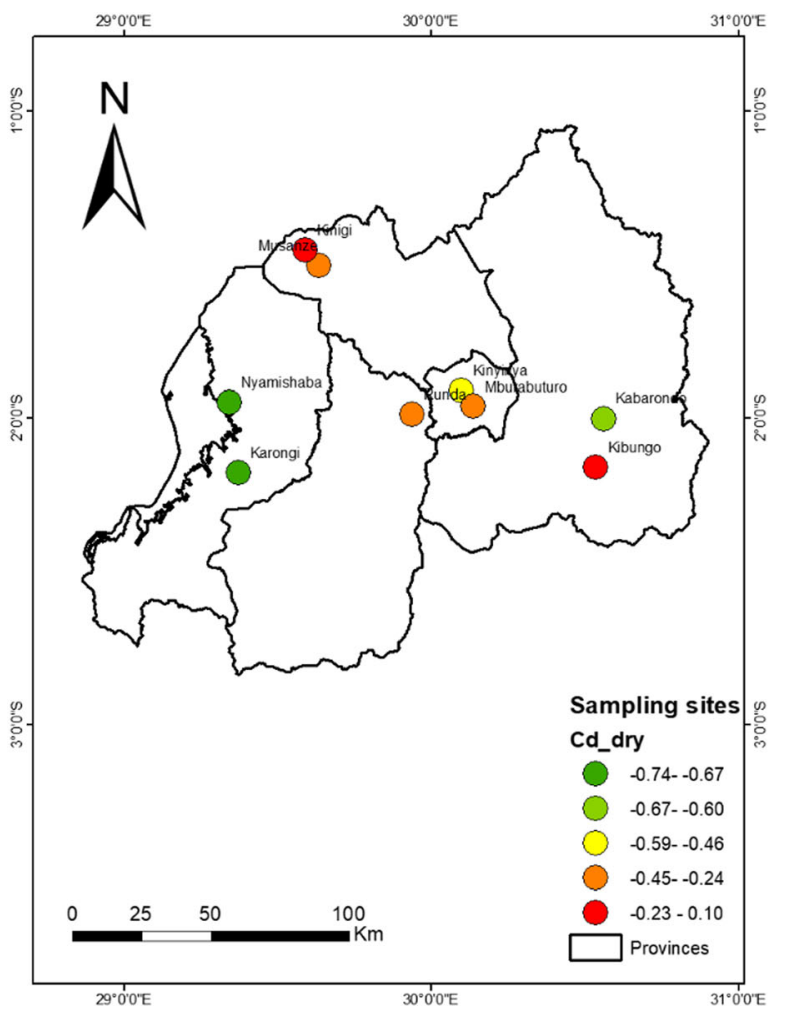

been provided such as provision of investment in water infrastructure maintenance, water reuse, recycle, flotation, chemical precipitation, ion exchange and membrane filtration and coagulation-flocculation, the rapid human population growth, and increase on-point and non-point

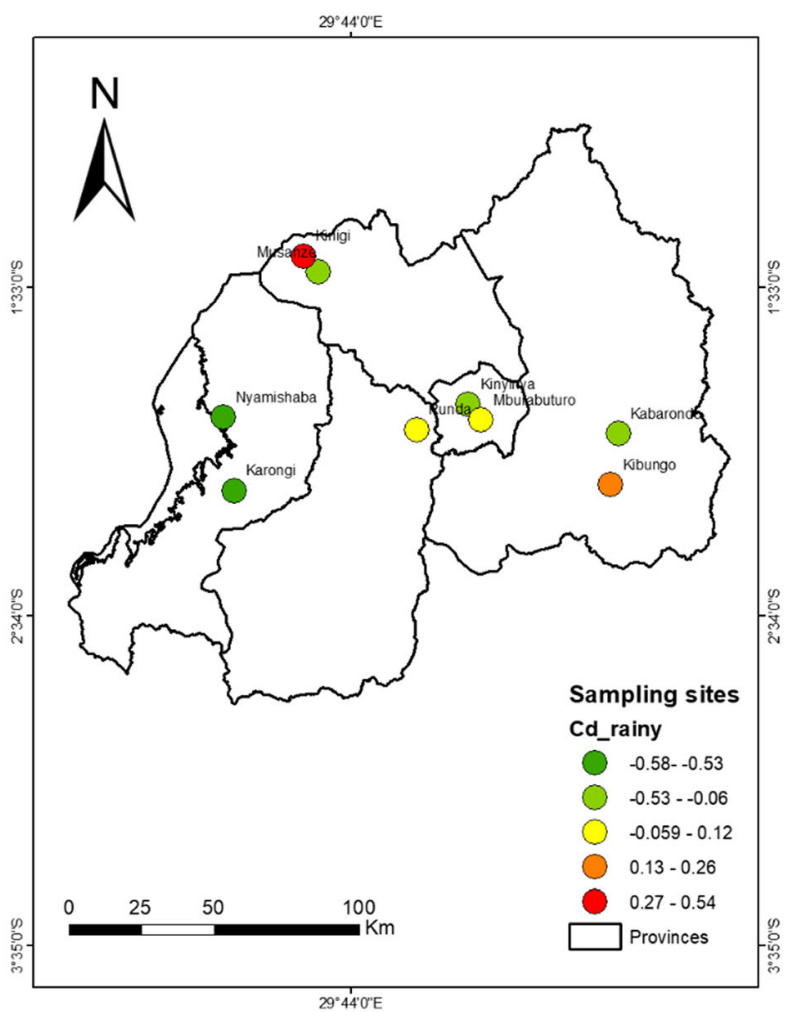

Fig. 10 Spatial distribution range of contamination degree $(\mathrm{Cd})$ for each sampling site 
drinking water pollution sources are threats to water quality. The government of Rwanda has launched the Integrated Water Resources Management (IWRM), an approach of developing, monitoring, and managing water resources. Nonetheless, for the policy to be fruitful and sustainable, there is a great need of managing the wastewater, the rapid expanding urbanization and informal settlements, and industrial and mining activities.

Therefore, this study employed metal index and contamination degree to compare the drinking water quality sources during the rainy and dry seasons by measuring for which extent the drinking water sources used are polluted. GIS has been used to spatially distribute the seasonal concentration of metal elements of drinking water sources in Rwanda. The results indicated that the mean value of iron and manganese exceeded the drinking water guidelines of the World Health Organization than other elements measured; also these elements were highly indexed than other monitored elements.

Therefore, the following are suggested for the water quality management in Rwanda under the abovementioned threats of water quality in Rwanda:

1. Since Rwanda is rich in precipitation throughout the year, it is good to consider maximum rain harvest; this will increase the underground storage and enables local communities to supply drinking water to their infrastructure and reduces sediments carried into source water which are the sources of metals in water.

2. The bench terraces and agroforestry techniques must be applied to minimize the sediments runoff.

3. It is suggested to promote environmental research and education and training on drinking water sources management from basic schools, hydrological data sharing and free access for water quality management enhancement, and to supervise the implementation of the buffer zones policy under execution in Rwanda.

4. Rapid population growth is increasingly leading to natural resource degradation; it is advised to set a fixed number of children per family with penalties or tax incentives to those disregarding the policy.

5. Population growth requires sufficient food, to do so, irrigation is proposed to boost the agricultural production; however, it is good to first check on environmental pros and cons of every irrigation technique (sprinkler and flood irrigation, drip irrigation) before use.

6. Rwanda as a developing country with high water demand, water re-use, the desalination would help much, where industrial, saline water, and household wastewater can be turned into usable water for other uses such as garden watering, carwash, and toilet uses. This will be a good option and reduce the wastewaterassociated consequences to water quality.

7. Although the government prioritized Crop Intensification Program (CIP), with one crop at appropriate location, it would be good to initiate and promote break crop system, different crops at once; this will enhance soil fertility and maintain soil at a level of not demanding high chemical fertilizers, and reduces water pollution.

8. Even though, environmental management is a cross cutting issue at every decision-making level, monitoring and evaluation of its execution and success basing on community's reality and national development plans are highly suggested.

Acknowledgments We are very grateful to the University of Chinese Academy of Sciences for the Scholarship awarded and the CAS Research Center for Ecology and Environment in Central Asia for its remarkable assistance. In addition, we express our gratitude to the Water and Sanitation Corporation (WASAC, Ltd.) for allowing and facilitating the water sample analysis.

Open Access This article is distributed under the terms of the Creative Commons Attribution 4.0 International License (http:// creativecommons.org/licenses/by/4.0/), which permits unrestricted use, distribution, and reproduction in any medium, provided you give appropriate credit to the original author(s) and the source, provide a link to the Creative Commons license, and indicate if changes were made.

\section{References}

Aboniyo, J., Umulisa, D., Bizimana, A., Pascal, J. M., \& Kwisanga, M. K. (2017). National water resources management authority for a sustainable water use in Rwanda. Sustainable Resources Management Journal, 2, 01-15.

Ali, D. A., Deininger, K., \& Goldstein, M. (2014). Environmental and gender impacts of land tenure regularization in Africa: pilot evidence from Rwanda. Journal of Development Economics, 110, 262-275. https://doi.org/10.1016/j. jdeveco.2013.12.009.

Allen, S., Qaim, M., \& Temu, A. (2013). Household water constraints and agricultural labour productivity in Tanzania. Water Policy, 15, 761-776. https://doi.org/10.2166 /wp.2013.174.

Backman, B., Bodiš, D., Lahermo, P., Rapant, S., \& Tarvainen, T. (1998). Application of a groundwater contamination index in Finland and Slovakia. Environmental Geology, 36, 55-64. https://doi.org/10.1007/s12665-013-2631-5. 
Bempah, C. K., \& Ewusi, A. (2016). Heavy metals contamination and human health risk assessment around Obuasi gold mine in Ghana. Environmental Monitoring and Assessment, 188, 261. https://doi.org/10.1007/s10661-016-5241-3.

Bidkhori, M., Yousefi, M., Rohani, H., Ebrahimi, H. \& Mohammadi, A. A. (2018). The influence of the use of improved sanitation facilities and improved drinking-water sources on the diarrhea-associated deaths in children under 5 years. Human and Ecological Risk Assessment: An International Journal, 1-8. https://doi.org/10.1080 /10807039.2018.1462089.

Byer, J. D., Struger, J., Sverko, E., Klawunn, P., \& Todd, A. (2011). Spatial and seasonal variations in atrazine and metolachlor surface water concentrations in Ontario (Canada) using ELISA. Chemosphere, 82, 1155-1160. https://doi.org/10.1016/j.chemosphere.2010.12.054.

Bakan, G., ÖZKOÇ, H. B., TÜLEK, S. \& CÜCE1T, H. 2010. Integrated environmental quality assessment of the Kizilırmak River and its coastal environment. Turkish Journal of Fisheries and Aquatic Sciences, 10.

Caeiro, S., Costa, M. H., Ramos, T., Fernandes, F., Silveira, N., Coimbra, A., Medeiros, G., \& Painho, M. (2005). Assessing heavy metal contamination in Sado Estuary sediment: an index analysis approach. Ecological Indicators, 5, 151-169. https://doi.org/10.1016/j.ecolind.2005.02.001.

Doyle, K., \& Shanahan, P. (2010). The impact of first flush removal on rainwater quality and rainwater harvesting systems' reliability in rural Rwanda. World Environmental and Water Resources Congress 2010: Challenges of. Change, 465-474. https://doi.org/10.1061/41114(371)52.

Elrashidi, M. A., Seybold, C. A., \& Wysocki, D. A. (2015). Effects of annual precipitation on heavy metals in runoff from soils in the US Great Plains. Water, Air, \& Soil Pollution, 226, 417. https://doi.org/10.1007/s11270-015-2684-z.

Goher, M. E., Hassan, A. M., Abdel-Moniem, I. A., Fahmy, A. H., $\&$ El-Sayed, S. M. (2014). Evaluation of surface water quality and heavy metal indices of Ismailia Canal, Nile River, Egypt. The Egyptian Journal of Aquatic Research, 40, 225233. https://doi.org/10.1016/j.ejar.2014.09.001.

Hosseinifard, S. J., \& Aminiyan, M. M. (2015). Hydrochemical characterization of groundwater quality for drinking and agricultural purposes: a case study in Rafsanjan plain, Iran. Water Quality Exposure and Health, 7, 531-544. https://doi. org/10.1007/s12403-015-0169-3.

Juahir, H., Zain, S. M., Yusoff, M. K., Hanidza, T. T., Armi, A. M., Toriman, M. E., \& Mokhtar, M. (2011). Spatial water quality assessment of Langat River Basin (Malaysia) using environmetric techniques. Environmental Monitoring and Assessment, 173, 625-641. https://doi.org/10.1007/s10661010-1411-x.

Karamage, F., Zhang, C., Ndayisaba, F., Nahayo, L., Kayiranga, A., Omifolaji, J. K., Shao, H., Umuhoza, A., Nsengiyumva, J. B., \& Liu, T. (2016). The need for awareness of drinking water loss reduction for sustainable water resource management in Rwanda. Journal of Geoscience and Environment Protection, 4, 74.

Khan, S. J., Deere, D., Leusch, F. D., Humpage, A., Jenkins, M., \& Cunliffe, D. (2015). Extreme weather events: should drinking water quality management systems adapt to changing risk profiles? Water Research, 85, 124-136. https://doi. org/10.1016/j.watres.2015.08.018.
Kirby, M. A., Nagel, C. L., Rosa, G., Iyakaremye, L., Zambrano, L. D., \& Clasen, T. F. (2016). Faecal contamination of household drinking water in Rwanda: a national crosssectional study. Science of the Total Environment, 571, 426-434. https://doi.org/10.1016/j.scitotenv.2016.06.226.

Low, K. H., Koki, I. B., Juahir, H., Azid, A., Behkami, S., Ikram, R., Mohammed, H. A., \& Zain, S. M. (2016). Evaluation of water quality variation in lakes, rivers, and ex-mining ponds in Malaysia. Desalination and Water Treatment, 57, 28215-28239.

Lumb, A., Sharma, T., \& Bibeault, J.-F. (2011). A review of genesis and evolution of water quality index (WQI) and some future directions. Water Quality Exposure and Health, 3, 1124. https://doi.org/10.1007/s12403-011-0040-0.

Lyulko, I., Ambalova, T. \& Vasiljeva, T. To integrated water quality assessment in Latvia. MTM (monitoring tailormade) iii. Proceedings of International Workshop on Information for Sustainable Water Management. Netherlands, 2001. 449452.

Mdegela, R., Braathen, M., Pereka, A., Mosha, R. D., Sandvik, M., \& Skaare, J. (2009). Heavy metals and organochlorine residues in water, sediments, and fish in aquatic ecosystems in urban and peri-urban areas in Tanzania. Water, Air, and Soil Pollution, 203, 369-379. https://doi.org/10.1007/s11270009-0019-7.

Mohan, S. V., Nithila, P., \& Reddy, S. J. (1996). Estimation of heavy metals in drinking water and development of heavy metal pollution index. Journal of Environmental Science \& Health Part A, 31, 283-289. https://doi.org/10.1080 /10934529609376357.

Mukanyandwi, V., Nahayo, L., Hakorimana, E., Gasirabo, A. \& Otgon, S. 2018. Review on water resources management and key threats in Rwanda, East Africa. Journal of Water Security, 4. https://doi.org/10.15544/jws.2018.003.

Nagar, R., Sarkar, D., Punamiya, P., \& Datta, R. (2015). Drinking water treatment residual amendment lowers inorganic arsenic bioaccessibility in contaminated soils: a long-term study. Water, Air, \& Soil Pollution, 226, 366. https://doi. org/10.1007/s11270-015-2631-z.

Nahayo, L., Li, L., Kayiranga, A., Karamage, F., Mupenzi, C., Ndayisaba, F., \& Nyesheja, E. M. (2016). Agricultural impact on environment and counter measures in Rwanda. African Journal of Agricultural Research, 11, 2205-2212. https://doi. org/10.5897/ajar2016.10899.

Nahayo, L., Mupenzi, C., Kalisa, E., Mukanyandwi, V., Gasirabo, A., \& Hakorimana, E. (2018). Seasonal drinking water quality monitoring for the community wellbeing in the Eastern Rwanda. Journal of Environment Protection and Sustainable Development, 4, 1-6.

Neogi, B., Tiwari, A. K., Singh, A. K. \& Pathak, D. (2018). Evaluation of metal contamination and risk assessment to human health in a coal mine region of India: a case study of the North Karanpura coalfield. Human and Ecological Risk Assessment: An International Journal, 1-13. https://doi. org/10.1080/10807039.2018.1436434.

Nhapi, I., Wali, U., Uwonkunda, B., Nsengimana, H., Banadda, N., \& Kimwaga, R. (2011). Assessment of water pollution levels in the Nyabugogo Catchment, Rwanda. Open Environmental Engineering Journal, 4, 40-53. https://doi. org/10.2174/1874829501205010056.

Nsengimana, H., Bigirimana, B., Suwa, M., Mukubwa, A., Debruyn, W., \& Kalisa, N. (2012). Assessment of heavy 
metals $(\mathrm{Pb}, \mathrm{Cu}, \mathrm{Cr}, \mathrm{Cd}$ and $\mathrm{Fe})$ in the groundwater wells in the vicinity of Nyanza Municipal Solid waste in Kigali CityRwanda. Rwanda Journal, 25, 3-21. https://doi.org/10.4314 /rj.v25i1.1.

Nyangababo, J., Henry, L., \& Omutange, E. (2005). Heavy metal contamination in plants, sediments, and air precipitation of katonga, simiyu, and nyando wetlands of Lake Victoria basin, East Africa. Bulletin of Environmental Contamination and Toxicology, 75, 189-196. https://doi.org/10.1007 /s00128-005-0737-5.

Onda, K., Lobuglio, J., \& Bartram, J. (2012). Global access to safe water: accounting for water quality and the resulting impact on MDG progress. International Journal of Environmental Research and Public Health, 9, 880-894. https://doi. org/10.3390/ijerph9030880.

Rahman, M. S., Saha, N., \& Molla, A. H. (2014). Potential ecological risk assessment of heavy metal contamination in sediment and water body around Dhaka export processing zone, Bangladesh. Environmental Earth Sciences, 71, 22932308. https://doi.org/10.1007/s12665-013-2631-5.

Rajeshkumar, S., Liu, Y., Zhang, X., Ravikumar, B., Bai, G., \& Li, X. (2018). Studies on seasonal pollution of heavy metals in water, sediment, fish and oyster from the Meiliang Bay of Taihu Lake in China. Chemosphere, 191, 626-638. https://doi.org/10.1016/j.chemosphere.2017.10.078.

Reza, R., \& Singh, G. (2010). Heavy metal contamination and its indexing approach for river water. International Journal of Environmental Science and Technology, 7, 785-792. https://doi.org/10.1007/bf03326187.

Rutanga, J., \& Niyigena, R. (2016). A comparative study of microbiological and physicochemical characteristics of water distributed from two water treatment plants in Rwanda.
Ethiopian Journal of Environmental Studies and Management, 9, 1-13. https://doi.org/10.4314/ejesm.v9i1.1.

Sahoo, M. M., \& Patra, K. C. (2018). Spatiotemporal evaluation of trace elements in river water using multivariate methods. Human and Ecological Risk Assessment: An International Journal, 1-25. https://doi.org/10.1080 /10807039.2018.1488214.

Scott, E. E., Leh, M. D., \& Haggard, B. E. (2017). Spatiotemporal variation of bacterial water quality and the relationship with pasture land cover. Journal of Water and Health, 15, 839848. https://doi.org/10.2166/wh.2017.101.

Srivastava, P., Mukherjee, S., Gupta, M., \& Singh, S. (2011). Characterizing monsoonal variation on water quality index of River Mahi in India using geographical information system. Water Quality Exposure and Health, 2, 193-203. https://doi.org/10.1007/s12403-011-0038-7.

Tiwari, A. K., De Maio, M., Singh, P. K., \& Mahato, M. K. (2015). Evaluation of surface water quality by using GIS and a heavy metal pollution index (HPI) model in a coal mining area, India. Bulletin of Environmental Contamination and Toxicology, 95, 304-310. https://doi.org/10.1007/s00128015-1558-9.

Wedgworth, J. C., \& Brown, J. (2013). Limited access to safe drinking water and sanitation in Alabama's Black Belt: a cross-sectional case study. Water Quality Exposure and Health, 5, 69-74. https://doi.org/10.1007/s12403-013-00880 .

Publisher's note Springer Nature remains neutral with regard to jurisdictional claims in published maps and institutional affiliations. 